Ilona RaUHala (Helsinki)

\title{
Attribuutin kongruenssi: adjektiivit, demonstratiivit ja *para
}

\section{Johdanto}

\section{I.I. Tutkimusaihe ja tavoitteet}

Tämä artikkeli käsittelee suomalais-permiläistä adjektiivia *para $(\rightarrow$ sm. parempi, paras, parantua); sen etymologiaa ja kongruenssia attribuuttiasemassa eri kielissä, joissa se esiintyy. Tutkimuksissa on toistuvasti kiinnitetty huomiota siihen, että saamessa, mordvassa ja komin Udoran murteessa adjektiivin *para vastineet käyttäytyvät toisin kuin muut adjektiivit (Itkonen 1966: 319; Bartens 1999: 108; 2000: 130). Näissä kielissä adjektiivit eivät yleensä pääsanansa edellä taivu, mutta *para-sanan vastineet ovat poikkeus: ne kongruoivat pääsanansa kanssa joko sijassa, luvussa tai molemmissa. Vertaan kyseistä adjektiivia muihin attribuuttiasemassa esiintyviin sanaluokkiin, siis pronomineihin ja numeraaleihin, ja tarkastelen näiden eroja ja yhtäläisyyksiä eri kielissä.

Tutkimukseni tavoitteena on osoittaa, että niissä kielissä, joissa sanan *para vastine poikkeaa attribuuttiasemassa muista adjektiiveista, se käyttäytyy samalla tavoin kuin demonstratiivipronominit. Huomionarvoista on myös se, että * para-sanan vastine poikkeaa muista adjektiiveista vain niissä kielissä, joissa demonstratiivipronominien attribuuttiaseman kongruenssi poikkeaa adjektiivien kongruenssista attribuuttiasemassa. Pohdin myös sitä, mitkä voisivat olla syitä tähän muista adjektiiveista poikkeavaan kongruenssiin.

Paitsi adjektiivia *para itsessään, tutkin myös erityisesti itämerensuomessa ja muutamissa saamelaiskielissä esiintyviä sekaparadigmoja, joihin *para liittyy. Bobaljik (2012) on typologiselta kannalta tutkinut vertailumuotojen sekaparadigmoja, ja hänen taulukoistaan (mts. 106-107) käy ilmi, että suurin osa hänen aineistossaan olevista sekaparadigmoista on 'hyvää' tarkoittavien adjektiivien vertailumuotoja (32 kpl). Toisena tulevat 'pahaa' tarkoittavien sanojen vertailumuodot $(22 \mathrm{kpl})$. Typologisesti katsottuna itämerensuomen ja saamelaiskielten sekaparadigmat ovat siis suorastaan odotuksenmukaisia.

\section{I.2. Etymologia ja levikki}

Sana *para 'hyvä' esiintyy nykykielistä suomessa sanan hyvä vertailumuodoissa (parempi, parhain, paras) sekä joidenkin johdettujen sanojen kantana (esim. parata, parantua), saamelaiskielissä, esimerkiksi pohjoissaamessa buorre 'hyvä' $(<$ ksaa *pōrē, Lehtiranta 2001: 110), ersässä paro 'hyvä' mokšassa para 'hyvä', marissa poro, 
puro 'hyvä, terve', komissa bur 'hyvä; oikea (käsi, puoli); onni, menestys, rikkaus' ja udmurtissa bur 'id.' (< kper. *bur, Csúcs 2005: 322) (UEW 1988: 724; SSA 2 313-314).

Koivulehdon (1999: 229) mukaan kyseessä on arjalainen laina $(<\mathrm{k}$-arj. *para $(s)$ 'hyvä; terve; vuosi'). Kantaindoeurooppalainen merkitys on varsin superlatiivinen *’normaalin ylittävä, pidemmällä, kauempana oleva', joten todennäköisesti suomen superlatiivi paras on lainattu suoraan muodosta * paras. ${ }^{1}$

Samasta kanta-arjan sanasta *para(s) on lainattu myös saamen (P) boaris (attr. boares) 'vanha' (Koivulehto 1999: 229). Varhaiskantasuomen muoto lainasta olisi ollut *poras, mistä ei voi odottaa tulevan itämerensuomeen muotoa para-. Saamen boaris onkin ns. $o$-laina ja suomen paras $a$-laina. Tämä tarkoittaa sitä, että kanta-arjalainen $* a$ on korvattu labiaalivokaalilla $*$, kun taas hieman nuoremmissa lainoissa k-arj. (tai kantairanilainen) $* a$ on substituoitu *a:lla. Esimerkkejä on suomessakin molemmista: orja $\leftarrow$ k.-arj. *arja ja sammas $\leftarrow$ (k.-)arj. *stamb ${ }^{h}$ as (> mint. stambhah 'patsas, pylväs'). Koivulehdon mukaan saamen boares ja mahdollisesti myös marin poro 'hyvä' sekä komin ja udmurtin bur 'hyvä' ovat vanhempaa perua kuin (itämeren)suomen paras. (Koivulehto 1999: 216, 229). Semanttisesti molemmat linkittyvät yhteen, sillä myös ims. sanalla on aikaan viittaavia merkityksiä, kuten parhaillaan, parastaikaa. Saamen sanalla boares ei ole vastineita muissa sukukielissä, ellei tähän yhdistetä sanaan *paras liitettyjä marin ja permin vastineita.

\section{Sanaluokat ja kongruenssi}

Kongruenssia tarkasteltaessa sanaluokkien määritteleminen on olennaista, sillä kongruenssi on erilaista eri sanaluokissa. Tosin, kuten edempänä todetaan, kongruenssi voi vaihdella myös sanaluokan sisällä. Sanaluokkia voidaan määritellä eri kriteerein: fonologisin, morfologisin, syntaktisin ja semanttisin (Pajunen 1998: 60). Samaan yhteyteen liittyy kysymys sanaluokkien kielikohtaisuudesta tai universaaliudesta. Typologiseen vertailuun sopivan, riittävän väljän, vertailukelpoisen ja kattavan terminologian kehittäminen kielen ilmiöille on haastava tehtävä, etenkin kun käytetyt termit ovat usein sekä kielikohtaisesti että typologisessa vertailussa samoja (ks. Haspelmath 2010).

Kognitiivisen lingvistiikan edustaja William Croft (1991: 94-95) on lähestynyt sanaluokkajakoa prototyyppisyyden kautta. Hän jakaa sanaluokat semanttisin ja pragmaattisin kriteerein ja toteaa, että jokaisella kielenpuhujalla on käsitys semanttisen luokan ja pragmaattisen funktion suhteesta, riippumatta siitä, miten ne kussakin kielessä ilmenevät.

Nominien ja verbien on oletettu kuuluneen kantauralin aikana eri kategorioihin (esim. Itkonen 1966: 228; Hakulinen 1979: 70), mutta esiuralilaisessa vaiheessa sanaluokkien rajan oletetaan olleen häilyvämpi. Tämä johtuu siitä, että uralilaisissa

1. Näin näyttää Koivulehtokin artikkelinsa hakusanan perusteella olettavan, vaikka ei asiaa mitenkään kommentoikaan. 
kielissä on sanaluokkia eroteltu lähinnä morfologisin perustein. Lisäksi sanajuuria, joista voi muodostaa sekä verbejä että nomineja (esim. tuule-), on käytetty perusteena sanaluokkien eriytymättömyydestä (esim. Hakulinen 1979: 70). Nämä piirteet on nähty jäänteinä aiemmasta, analyyttisesta kielivaiheesta. Tähän on kuitenkin parikin vasta-argumenttia. Ensinnäkin myös analyyttiset kielet erottavat pääsanaluokat toisistaan (Itkonen 2001: 17). Toisekseen maailman kielten joukosta ei tunneta yhtään sellaista kieltä, joka ei jollakin kriteerillä erottelisi sanaluokkia toisistaan (Pajunen 1998: 99). Uralilaisissa kielissä nominit ja verbit voidaan erottaa semanttisin ja muodollisin kriteerein, ja Pajusen (ibid.) mukaan samoilla kriteereillä voidaan uralilaisissa kielissä myös substantiivit ja adjektiivit erottaa toisistaan. Samojedissa, toisin kuin muissa uralilaisissa kielissä, osa adjektiivisista sanoista on verbejä, osa nomineja. Jalava (2013) kuitenkin osoittaa, että nominimuotoiset adjektiivit ovat vanhempaa perua kuin verbimuotoiset, jotka ovat kielikontaktien tulosta.

Typologisessa tutkimuksessa kongruenssin käsite hieman vaihtelee koulukunnittain. Esim. Corbett (2006: 21, 133-135) ei pidä sijakongruenssia kanonisena kongruenssina, vaan olettaa, että nominaalilausekkeen kongruenssin laukaisee ulkoinen määrääjä (governee), siis rektio (ks. esimerkki 1).

$\begin{array}{lll}\text { (1) } & v \quad \text { nov-om } & \text { avtomobil-e } \\ \text { PREP } & \text { uusi-M.SG.LOC } & \text { auto(M)-SG.LOC } \\ \text { 'uudessa autossa' } & \end{array}$

(Corbett 2006: 133)

Corbettin mukaan attribuutin ja pääsanan välillä täytyy vallita symmetrinen kongruenssi, ts. attribuutin ja pääsanan sijojen täytyy olla samankaltaisia. Venäjässä kuitenkaan adjektiivi ei voi saada samanmuotoisia sijoja kuin substantiivi, kun taas esim. suomessa attribuutin ja pääsanan sijat ovat muodollisesti yhtenevät ja kongruenssi on symmetrinen. Uskottavampi ja esim. suomen kannalta toimivampi on dependenttiteoria (Mel'čuk 1993: 329, 337; Rießler 2011: 50-52), jossa adjektiiviattribuutin sijan määrää pääsana (substantiivi), ei siis mikään nominilausekkeen ulkopuolinen jäsen.

Kongruenssin vaihtelu saman sanaluokan sisällä ei ole tavatonta. Esimerkiksi swahilissa (Baker 2008: 39) osa adjektiiveista kongruoi suvussa pääsanansa kanssa attribuuttiasemassa, osa ei. Samoin ranskassa adjektiivit jakautuvat sen mukaan, mihin ne attribuuttina sijoittuvat: pääsanan eteen vai taakse. Yleisimmin käytetyt adjektiivit sijoittuvat pääsanansa eteen, muut taakse. Nämä adjektiivit viittaavat kokoon (petit 'pieni'), ikään (nouveau 'uusi') ja arvoon (bon 'hyvä') (Moilanen \& Natri 1995: 41-42). Tällaisissa tapauksissa kyse voi olla jonkinlaisesta semanttisesta jaosta adjektiivien kesken. Dixon (2004: 3-4) jakaa adjektiivit semanttisiin ryhmiin, joita on kaikkiaan kaksitoista. Hänen mukaansa kaikissa kielissä on adjektiiveja, jotka viittaavat vähintään seuraaviin ominaisuuksiin: 1. laajuus ('suuri', 'pieni'), 2. ikä ('nuori', 'vanha'), 3. arvo ('hyvä', 'huono'), 4. väri ('musta', 'punainen'). Onkin mahdollista, että adjektiivikategorian muuttuessa näihin neljään kategoriaan viittaavat sanatyypit ovat niitä vanhimpia ja, mikäli poikkeavat muista adjektiiveista, 
edustavat vanhempaa kantaa. Näin näyttäisi olevan esimerkiksi tundranenetsissä (Jalava 2013), jossa vanhimmat adjektiivit viittaavat näihin neljään kategoriaan ja ovat nominimuotoisia, eivät verbejä, kuten monet muut adjektiivit. Näihin ryhmiin voi tulla kuitenkin myös uusia sanoja. Tundranenetsissäkin osa näiden kategorioiden sanoista on verbimuotoisia (esim. príid'e- '(olla) musta'). Kuitenkin etymologisesti vanhimmat adjektiivit kuuluvat yleensä näihin neljään kategoriaan ja nenetsissä ne ovat nomininkaltaisia (Jalava 2013: 20).

Areaalilingvistiikan näkökulmasta Pohjois-Euraasian kielissä yleisimmät adjektiiviattribuuttirakenteet ovat kongruoimaton attribuutti (juxtaposition), jota edustavat monet uralilaiset ja turkkilaiset kielet, ja pääsanan mukainen kongruenssi (head-driven agreement), jota esimerkiksi itämerensuomi ja slaavilaiskielet edustavat (Rießler 2011: 178).

Kuten monissa uralilaisissa kielissä nykyään, myös kantauralissa adjektiivit (mikäli ne ovat olleet oma sanaluokkansa) eivät ole attribuuttiasemassa kongruoineet pääsanansa kanssa (Ravila1960: 28). Yleensäkin kongruenssi on tuntematon SOVkielille (Honti 1997: 135), jota kantaurali on edustanut.

Pronominien ja numeraalien suhde pääsanaan on kuitenkin ollut monisyisempi kuin adjektiivien. Ravila (1960: 31-35) olettaa, että pronominien ja numeraalien kongruenssi on vanha ilmiö ja siten siemen myös adjektiiviattribuutin kongruenssin syntyyn itämerensuomalaisissa kielissä. Ravilan mukaan tyyppi *tänä kotana olisi alkuaan sellainen, että pronomini on pääsana ja substantiivi sen määrite, appositio. Näin siis on määrite kongruoinut pääsanansa kanssa. Tästä olisi syntynyt myös itämerensuomen adjektiivien kongruenssi. Osoituksena tämänkaltaisesta kehityksestä Ravila pitää sitä, että itämerensuomessa attribuutin kongruenssi ei koske persoonapäätteitä, esim. sm. suuressa talossani, ei *suuressani talossani, pronomineihin kun ei ole yleensä possessiivisuffikseja liittynyt. Toisekseen, pronominiattribuutin ja pääsanan kongruenssia esiintyy monessakin uralilaisessa kielessä joitakin samojedikieliä myöten (ks. Honti 1997). Onkin oletettavaa, että demonstratiivipronomini + substantiivi -appositiorakenteesta on kongruenssi levinnyt myös adjekiiviattribuuttirakenteeseen eri kielissä. Siksi kongruenssi-ilmiöön ei esim. Hontin (1997: 14) mukaan tarvitse kielikontaktien vaikutusta olettaa. Ympäröivät kielet voivat kuitenkin edesauttaa kongruenssin laajenemista.

Sanan *para kongruenssi tuo attribuuttimuotojen kongruenssiin lisäkysymyksiä. Sen kongruenssi vaikuttaa suunnilleen yhtä arkaaiselta kuin pronominien, mutta kaikissa nykykielissä se on adjektiivi, joiden puolestaan oletetaan alkuaan olleen taipumattomia attribuuttiasemassa. Seuraavassa esittelen aineistoa niistä kielistä, joissa *para esiintyy, ja pohdin, miten se rinnastuu muihin suomalais-ugrilaisissa kielissä esiintyviin kongruenssi-ilmiöihin. 


\section{Attribuuttiasemassa esiintyvät elementit: adjektiivit, numeraalit, demonstratiivipronominit ja *para}

\section{I. Itämerensuomi}

Itämerensuomen attribuuttikongruenssista on kirjoitettu jo paljon, viimeisimpänä Michael Rießler (2011: 146-147), jonka mukaan itämerensuomen adjektiiviattribuutin kongruenssi on tyyppiä head-driven agreement. Itämerensuomessa sekä adjektiivit, numeraalit että demonstratiivipronominit kongruoivat pääsanansa luvun ja sijan mukaisesti. Eri aikoina on korostettu kielikontaktien, erityisesti germaanisten kontaktien, merkitystä itämerensuomen attribuuttikongruenssin synnyssä. Kuitenkin esim. Hontin (1997: 141-142) mukaan kyse on eri uralilaisissa kielissä kehittyneen demonstratiivipronomini + substantiivi -kongruenssin laajeneminen numeraali- ja adjektiiviattribuutteihin. Tähän ovat saattaneet ympäröivien kielten systeemit myötävaikuttaa, mutta lähtökohta on ollut kielessä jo ennestään.

Itse sana *para on itämerensuomessa osittain syrjäytetty paradigmastaan. Se esiintyy 'hyvää' tarkoittavana vain paradigmansa komparatiivi- ja superlatiivimuodoissa (parempi, paras/parhain). Positiivina esiintyy hyvä, joka on myös vanha sana (= saaP savvit 'parantaa', mdE tšiv 'hyvä, kelvollinen' mdM tšiva 'vieraanvarainen'). SSA:ssa (I 201) esitetään epävarmoja rinnastuksia kauempaakin. Sana hyvä on lainattu samasta suunnasta kuin *para. Se on iranilainen lainasana, jonka levikki ulottuu mordvaan ( $\leftarrow$ vkiran. *tsiva-, vrt. mint. śivá- 'suopea, hyväntahtoinen, ystävällinen, rakas', Koivulehto 2009: 85-87). Kyse ei siis näytä olevan siitä, että vanha *para olisi positiivissa korvattu nuoremmalla sanalla, vaan kielessä toisessa merkityksessä ollut sana on syystä tai toisesta ottanut paradigmasta positiivin paikan.

\subsection{Saamelaiskielet}

\subsection{Adjektiivit}

Saamelaiskielissä adjektiivit eivät attribuuttiasemassa taivu pääsanansa mukaisesti. Lisäksi adjektiivit saavat oman, erillisen attribuuttimuodon, esim. saaP ruoksat (pred.), rukses (attr.) 'punainen'. Nykyisten saamelaiskielten attribuuttijärjestelmä on sikäli yhteneväinen, että se voidaan palauttaa kantasaameen saakka (Korhonen 1981: 345; Rießler 2011: 213-226).

Pohjoissaamessa vallitsee attribuuttimuodoissa inkongruenssi tietyin poikkeuksin. Poikkeuksia ovat adjektiivit buorre (<* para) ja bahá, peruslukusanat, järjestyslukusana nubbi 'toinen' (joka myös on alkuaan pronomini, ks. Korhonen 1981: 92; SSA 2: 185) sekä useimmat pronominit (Korhonen 1981: 344). Nämä kongruoivat pääsanansa kanssa osittain, mikä tarkoittaa sitä, että joissakin sijoissa attribuutti on eri sijassa kuin pääsana (2a), mutta joissakin sijoissa attribuutti seuraa pääsanansa sijamuotoa (2b). Yleensä tällaista ilmiötä on nimitetty puolikongruenssiksi 
(Korhonen 1981: 344), joissain tapauksissa heikoksi taivutukseksi (Bartens 1972: 155-160; Moshnikoff \& Koponen 2009: 51). Tässä artikkelissa kutsun ilmiötä puolikongruenssiksi.

$\begin{array}{lllll}\text { (2) a. } \quad M u \quad \text { buorre } & \text { niibbi-s lea } & \text { ráigi. } \\ & \text { 1sG.Gen hyvä.ATTR } & \text { veitsi-Loc olla.PRs.3sg } & \text { reikä.Nom } \\ & \text { 'Minun hyvässä veitsessäni on reikä.' } & \end{array}$
b. Mun bohten buri-in niibbi-in.
1sG.Nom tulla.PRET.1sg hyvä-com veitsi-com
'Minä tulin hyvän veitsen kanssa.'

Eteläsaamessa adjektiivien syntaktinen käyttäytyminen eroaa varsin paljon pohjoissaamesta. Vanha, kantasaamesta periytyvä attribuuttimuoto voi monessa tapauksessa esiintyä myös predikatiivina, esim. guhkies (attr./pred.), guhkie (vain pred.), mikä saattaa viitata attribuuttijärjestelmän murenemiseen (ks. Rießler 2011: 189).

Eteläsaamessa ja koltassa komparatiivimuodot voivat kongruoida pääsanansa kanssa. Koltassa kongruenssi on osittaista demonstratiivipronominien tapaan (Moshnikoff \& Koponen 2009: 51). Eteläsaamessa adjektiivin komparatiivi kongruoi pääsanansa kanssa luvussa, mutta ei sijassa (Bergsland 1994: 52). Vertailuasteiden kongruenssia ei esimerkiksi pohjoissaamessa esiinny.

Esimerkistä ( $3 \mathrm{a}-\mathrm{c})$ käy ilmi, miten komparatiivimuoto kongruoi pääsanansa kanssa eteläsaamessa. Huomattavaa on myös, että predikatiivilauseessa ei ole kopulaa, toisin kuin pohjoissaamessa (ibid.):
(3) a. Pïre nuere-be
Per.sg.Nom nuori-CMPR.SG.NOM
'Per on nuorempi'.
b. Dah nuere- $b-h$
DEM.PRON.PL.NOM nuOri-CMPR-PL.NOM
'He ovat nuorempia'.
c. Nuere-b-h dah
nuori-CMPR-PL.NOM DEM.PRON.PL.NOM
'He ovat nuorempia'

Komparatiivi- ja superlatiivimuotojen kongruenssia esiintyy myös itäisissä saamelaiskielissä (Itkonen 1966: 319), joten mitenkään uusi ilmiö vertailumuotojen kongruenssi ei saamelaiskielissä ole. Eteläsaamen kongruenssi poikkeaa koltan kongruenssisysteemistä siinä määrin, että nämä eivät palautune yhteiseen kongruenssiin, vaan eteläsaamen kongruenssi lienee myöhäisemmän kehityksen tulos. 


\subsubsection{Demonstratiivipronominit}

Saamelaiskielissä demonstratiivipronominit ovat puolikongruenssissa pääsanansa kanssa. Ravilan (1960: 34) mukaan kyse tällaisessa kongruenssissa on siitä, että demonstratiivipronomini on pääsana ja substantiivi määrittää sitä. ${ }^{2}$

Demonstratiivipronominien kongruenssi vaihtelee hieman kielittäin ja murteittain. Pohjoissaamessa demonstratiivit kongruoivat yleisissä sijoissa (nominatiivi, genetiivi-akkusatiivi, essiivi, komitatiivi). Yksikön illatiivista ja lokatiivista kongruenssi puuttuu ja pronomini on genetiivi-akkusatiivissa. Monikossa kongruenssi on laajempi ulottuen myös illatiiviin ja lokatiiviin (kaavio 1.).

\begin{tabular}{|c|c|c|}
\hline \multicolumn{3}{|c|}{ 'tuo talo' } \\
\hline & yksikkö & monikko \\
\hline NOM & dat dállu & dat dálut \\
\hline GEN/ACC & dan dálu & daid dáluid \\
\hline ILL & dan dállui & daidda dáluide \\
\hline LOC & dan dálus & dain dáluin \\
\hline сом & dainna dáluin & daid dáluiguin, daiguin dáluiguin \\
\hline ESS & & n dállun \\
\hline
\end{tabular}

Taulukko I. Demonstratiivipronominin attribuuttitaivutus pohjoissaamessa (Nickel 1994: II6).

Itäsaamessa akkusatiivi ja genetiivi ovat säilyneet erillään. Abessiivista on tullut sijapääte, jonka edessä attribuutti on genetiivissä. Partitiivissa tätä konstruktiota ei esiinny lainkaan. Esimerkki inarinsaamen demonstratiivipronominien kongruenssista (taulukko 2):

\begin{tabular}{|l|l|l|}
\hline 'tuo kala' & \multicolumn{2}{l|}{} \\
\hline & yks. & mon. \\
\hline NOM & taat kyẹli & taah kye'leh \\
\hline GEN & taan kye'le & tai kuo(')lij \\
\hline ACC & taam kye'le & täid kuolijd \\
\hline ILL & taan kuálan & taaid $\sim$ tááid kuolijd \\
\hline LOC & taan kye'leest & täin kuolijn \\
\hline COM & tain kuolijn & tai kuo'lijgijn \\
\hline ABESS & taan kye'lettáá & tai kuo'lijttáá \\
\hline ESS & tanen kyellin & \\
\hline PART & & \\
\hline
\end{tabular}

Taulukko 2. Demonstratiivipronominin attribuuttitaivutus inarinsaamessa (Olthuis 2000: 180).

2 Laajemmin inarinsaamen, merisaamen ja luulajansaamen sijakongruenssista ks. Bartens 1972: $155-164$. 
Toisin kuin pohjois- ja inarinsaamessa, eteläsaamessa inessiivi ja elatiivi ovat erillisiä sijamuotoja. (Taulukko 3.) Eteläsaamen kongruenssi on siinä mielessä monisyisempi, että demonstratiivipronominit eivät valitse täysin samoja sijoja kuin pääsanalla on. Demonstratiivipronomini on illatiivin edellä genetiivissä (Korhosen mukaan latiivi), inessiivin edellä essiivissä ja elatiivin edellä partitiivissa (Korhonen 1981: 345).

\begin{tabular}{|c|c|c|}
\hline \multicolumn{3}{|c|}{ 'tämä talo' } \\
\hline & yks. & mon. \\
\hline NOM & daate gåetie & daah gåetieh \\
\hline $\mathrm{ACC}$ & daam gåetiem & daejtie gåetide \\
\hline GEN & daan gåetien & daaj gåetiej \\
\hline ILL & daan gåatan & daejtie gåetide \\
\hline INESS & daennie gåetesne & daejnie gåetine \\
\hline EL & daehtie gåeteste & daejstie gåetijste \\
\hline $\mathrm{COM}$ & daejne gåetine & daaj gåetiejgujmie \\
\hline
\end{tabular}

Taulukko 3. Demonstratiivipronominien attribuuttitaivutus eteläsaamessa (Bergsland 1994: 125).

Korhosen (1981: 345) mukaan eteläsaamen edustama puolikongruenssi (taulukko 3) on alkuperäisin. Varhaisemmassa järjestelmässä pääsana on ollut sisäisessä ja attribuutti yleisessä paikallissijassa. Luultavasti juuri eteläsaamen edustuksen perusteella Korhonen pitää tätä kongruenssityyppiä varsin arkaaisena.

\subsubsection{Numeraalit}

Saamelaiskielissä myös perusluvut kongruoivat pääsanansa kanssa. Numeraalien kongruenssi saattaa kielittäin ja murteittain vaihdella verrattuna pronominien kongruenssiin. Alla esimerkki inarinsaamesta (taulukko 4):

\begin{tabular}{|l|l|l|}
\hline & 'yksi kala' & 'kolme kalaa' \\
\hline NOM & ohtâ kyeli & kulmâ kye'le \\
\hline GEN & oovtâ kye'le & kuulmâ kye'le \\
\hline ACC & oovtâ kye'le & kulmâ kye'le \\
\hline ILL & oovtâ kuálán $\sim$ kuálân & kuulmâ kuálán $\sim$ kuálân \\
\hline LOC & oovtâ kye'leest & kuulmâ kyeleest \\
\hline COM & ovttáin kuolijn & kulmáin kuoljin \\
\hline ABESS & oovtâ kye'lettáá & kuulmâ kye'lettáá \\
\hline ESS & ohtân kyellin & kulmân kyellin \\
\hline PART & - & - \\
\hline
\end{tabular}

Taulukko 4. Lukusanojen ohtâ 'yksi' ja kulmâ 'kolme' attribuuttikongruenssi inarinsaamessa (Olthuis 2000: 187). 
Inarinsaamessa lukusanalla ohtâ ei ole erillistä akkusatiivimuotoa, mutta lukusanoilla kyehti-vihtta (2-5) on erillinen akkusatiivimuoto (vahva aste), mikä siis seuraa demonstratiivipronominien kongruenssia. Myös pohjoissaamessa lukusana okta 'yksi' on samassa muodossa sekä genetiivissä että akkusatiivissa (kuten demonstratiivipronomini), mutta guokte 'kaksi' ja sitä suuremmat ovat eri sijoissa, siten että akkusatiivimuoto on vahvassa asteessa, aivan kuten inarinsaamessa (Nickel 1994: 89, ks. taulukko 5). Demonstratiivien ja numeraalien kongruenssi eroavat toisistaan genetiivin ja akkusatiivin osalta. Akkusatiivi ja genetiivi ovat pohjoissaamessa numeraaleja lukuun ottamatta langenneet yhteen. Syy akkusatiivin säilymiseen numeraaleissa näyttää olevan astevaihtelu, joka on säilyttänyt erillisen akkusatiivimuodon. Muualla pohjoissaamen taivutuksessa genetiivi-akkusatiivi on heikossa asteessa.

\begin{tabular}{|l|l|l|}
\hline & 'yksi kala' & 'kaksi kalaa' \\
\hline NOM & okta guolli & guokte guoli \\
\hline GEN & ovtta guoli & guovtti guoli \\
\hline ACC & ovtta guoli & guokte guoli \\
\hline ILL & ovtta guollái & guovtti guollái \\
\hline LOC & ovtta guolis & guovtti guolis \\
\hline COM & ovttain guliin & guvtiin guliin \\
\hline ESS & oktan guollin & guoktin guollin \\
\hline
\end{tabular}

Taulukko 5. Numeraalien okta 'yksi' ja guokte 'kaksi' attribuuttitaivutus pohjoissaamessa (Nickel 1994: 89).

Myös eteläsaamessa numeraalien (taulukko 6) taivutus eroaa jonkin verran pronominien taivutuksesta. Suurin eroavuus on siinä, että elatiivissa attribuuttimuoto on aktede, kun demonstratiivilla attribuutissa on muoto -htie (ks. taulukko 3). Myös monikossa on eroja: demonstratiiveilla nominatiivi, akkusatiivi ja genetiivi ovat kaikki erimuotoisia, mutta numeraaleilla monikon nominatiivi ja akkusatiivi ovat samannäköiset.

\begin{tabular}{|c|c|c|c|c|}
\hline & 'yksi talo' & 'yhdet kengät' & 'kaksi taloa' & 'kahdet kengät' \\
\hline NOM & akte gåetie & akth gaamegh & göökte gåetieh & göökth gaamegh \\
\hline AKK & aktem gåetim & akth gaamegh & göökte gåetieh & gööth gaamegh \\
\hline GEN & akten gåetien & akti gaamegi & $\begin{array}{l}\text { guektien } \\
\text { gåatien }\end{array}$ & göökti gaamegi \\
\hline ILL & akten gåatan & $\begin{array}{l}\text { aktide } \\
\text { gaamegidie }\end{array}$ & guektien gåatan & $\begin{array}{l}\text { gööktide } \\
\text { gaamegidie }\end{array}$ \\
\hline INESS & $\begin{array}{l}\text { aktene } \\
\text { gåetesne }\end{array}$ & $\begin{array}{l}\text { aktine } \\
\text { gaameginie }\end{array}$ & $\begin{array}{l}\text { gööktene } \\
\text { gåetesne }\end{array}$ & $\begin{array}{l}\text { gööktine } \\
\text { gaameginie }\end{array}$ \\
\hline ELAT & $\begin{array}{l}\text { aktede } \\
\text { gåeteste }\end{array}$ & $\begin{array}{l}\text { aktijste } \\
\text { gaamegisjstie }\end{array}$ & $\begin{array}{l}\text { gööktede } \\
\text { gåeteste }\end{array}$ & $\begin{array}{l}\text { gööktijste } \\
\text { gaamegijstie }\end{array}$ \\
\hline KOMIT & $\begin{array}{l}\text { aktine } \\
\text { gåetine }\end{array}$ & $\begin{array}{l}\text { akti } \\
\text { gaamegigujmie }\end{array}$ & $\begin{array}{l}\text { gööktine } \\
\text { gåetine }\end{array}$ & $\begin{array}{l}\text { göökti } \\
\text { gaamegigujmie }\end{array}$ \\
\hline
\end{tabular}

Taulukko 6. Lukusanojen attribuuttikongruenssi eteläsaamessa (Bergsland 1994: 132). 
Järjestysluvuista pohjoissaamessa ainoastaan nubbi 'toinen' kongruoi pääsanansa kanssa ja sen kongruenssi seuraa demonstratiivipronominien kongruenssia (Nickel 1994: 92). Kyseessä on alkuaan pronomini, mikä voi selittää kongruenssin esiintymisen juuri tällä muodolla. Toinen, ei välttämättä edellistä sulkeva vaihtoehto on, että kyse on jäänteestä. Etelä-, inarin- ja koltansaamessa komparatiivi- ja superlatiivimuodot kongruoivat pääsanansa kanssa, ja sanan nubbi toinen tavu palautuu komparatiiviin, < vksm. *muи-mpa (Korhonen 1981: 247). Tukea tähän antaa se, että inarinsaamessa myös järjestysluku vuos(s)muš 'ensimmäinen' kongruoi pääsanansa kanssa samalla tavoin kuin kaaviossa 4. esitetty ohtâ (Olthuis 2000: 187). Syynä tähän kongruenssiin on se, että sana on johdettu superlatiivijohtimella -muš, joka on kongruenssin piirissä (Olthuis 2000: 171).

Eteläsaamessa järjestysluvun mubpie 'toinen' lisäksi myös suuremmat järjestysluvut voivat kongruoida pääsanansa mukaisesti (Bergsland 1994: 133). Tässä paradigmassa voi olla kyse kongruenssin analogisesta laajenemisesta yhdestä järjestysluvusta suurempiin.

\subsubsection{Buorre}

Pohjoissaamen buorre 'hyvä' kongruoi samalla tavalla kuin demonstratiivipronominit (taulukko 7):

\begin{tabular}{|l|l|l|}
\hline \multicolumn{2}{|l|}{ 'hyvä veitsi' } & Monikko \\
\hline NOM & buorre niibi & buorit niibbit \\
\hline GEN/ACC & buori niibbi & buriid niibbiid \\
\hline ILL & buori niibái & $\begin{array}{l}\text { buriid niibbiide, } \\
\text { buriide niibbiide }\end{array}$ \\
\hline LOC & buori niibbis & buriid niibbiin \\
\hline COM & buriin niibbiin & $\begin{array}{l}\text { buriid niibbiiguin } \\
\text { buriiguin niibbiiguin }\end{array}$ \\
\hline
\end{tabular}

Taulukko 7. Sanan buorre attribuuttikongruenssi pohjoissaamessa (Nickel 1994: 82).

Inarinsaamen sana pyeri 'hyvä' kongruoi yksikössä ennemmin lukusanan ohtâ kuin demonstratiivin mukaisesti (taulukko 8). Ero koskee ainoastaan akkusatiivin ja genetiivin eron merkintää, joka sanalta pyeri puuttuu, aivan kuten pohjoissaamesta. 


\begin{tabular}{|l|l|l|}
\hline \multicolumn{3}{|l|}{ 'hyvä matka' } \\
\hline \multicolumn{2}{|c|}{ yks. } & mon. \\
\hline NOM & pyeri mätki & pye'reh määđhid \\
\hline GEN & pye're määđhi & puo(')rij ma(a)dhij \\
\hline ACC & pye're määđhi & puorijd maadhijd \\
\hline ILL & pye're máátkán & puori(i)jd mađhi(i)jd \\
\hline LOC & pye're määđhist & puorijn maađhijn \\
\hline COM & puorjin mađhi(i)jn & puo(')rij mađhijgijn -gui'm \\
\hline ABESS & pye're mäđhittáá & puo(')rij mađhijttáá \\
\hline ESS & \multicolumn{2}{|c|}{ pyerrin mätkin } \\
\hline PART & pyerrid mätkid \\
\hline
\end{tabular}

Taulukko 8. Inarinsaamen pyeri-attribuuttimuodon kongruenssi (Olthuis 2000: 172).

Luulajansaamen buorre kongruoi pääsanansa kanssa vain pohjoismurteissa. Etelämpänä se on taipumaton, eikä siis eroa muista adjektiiveista (LuLpW 1953: 1843.) Myöskään arjeploginsaamessa sanan puorrie kongruenssi ei vaikuta pakolliselta (Lehtiranta 1992: 122). Eteläsaamessa *para-sanan vastine buorie esiintyy vain komparatiivi- ja superlatiivimuodoissa, aivan kuten suomessa. Lisäksi se esiintyy yksittäisissä ilmauksissa: buorie biejjie 'hyvää päivää'. Yksikön nominatiivi on hijven 'hyvä', eikä se kongruoi pääsanansa kanssa attribuuttiasemassa. Eteläsaamen täydennysparadigma näyttää olevan suora laina (metsä)suomen systeemistä hyvä, parempi, paras (saaE hijven $\leftarrow$ sm. hyvin) ${ }^{3}$. Näyttää siis siltä, että luulajansaamen pohjoismurteista etelään päin *para-sanan kongruenssi on katoamassa.

Pohjoissaamessa myös bahá 'paha, huono', kongruoi yksittäistapauksissa samaan tapaan kuin buorre. Äännerakenteensa perusteella se on nuori tai nuorehko laina itämerensuomesta (SSA 2: 286), minkä vuoksi mitään arkaaista kongruenssin jäännettä ei voi tähän olettaa. Ennemmin kongruenssiin on syynä se, että sanat bahá ja buorre ovat vastakohtaisia ja esiintyvät usein rinnakkain (esim. buriin ja baháin beivviin 'hyvinä ja pahoina päivinä'). Tällainen rinnakkaisuus voi vetää mukaansa joko runollisesta syystä tai analogian vuoksi.

Inarinsaamessa on myös muita pääsanansa mukaan kongruoivia adjektiiveja kuin pyeri. Monikossa niiden supistumavartaloisten adjektiivien, joilla ei ole erillistä attribuuttimuotoa, attribuutti usein kongruoi pääsanansa kanssa sekä sijassa että luvussa. Attribuutin kongruenssia esiintyy seuraavilla päätteillä: -lâs (esim. anolâs 'käyttökelpoinen'), -lâš (sämmilâš 'saamelainen'), -muš (majemuš 'viimeinen'4), -sâš (ahasâš 'ikäinen') ja -vaš (oppâvâš 'oppivainen'). Olthuisin (2000: 171-172) mukaan attribuutin kongruenssi ei ole pakollista, kun taas Bartensin (1972: 156)

3. Florian Sieglin ja Ante Aikion välinen keskustelu, jota ensin mainittu on minulle referoinut.

4. Huomaa, että kyseessä on superlatiivin johdin. 
mukaan - $d \check{z}$-aineksisten adjektiivien (kuten edellä olevat) kongruenssi on pakollista. Tällaisessa vapaaehtoisessa kongruenssissa lienee kysymys tähdentämisestä, psykologisesta painotuksesta (Erkki Itkoseen viitaten Bartens 1972: 158).

Lisäksi kongruenssia esiintyy muutamilla kolmitavuisilla adjektiiveilla, joista suurimmalla osalla on erillinen attribuuttimuoto (hiđes, attr. hittáás 'hidas', kirkes, attr. kirkká(s) 'kirkas', kuá'rus 'tyhjä', puáris, attr. puár'rás 'vanha', putes, attr. puttá(s) 'puhdas') sekä sanoilla julme 'julma; (liian) suuri' ja šiev 'hyvä'(Olthuis 2000: 171-172). InLpW:n (s. 214) mukaan šiev on attribuuttiasemassa taipumaton adjektiivi, kun taas Olthuis (2000: 172) laskee sen kongruenssin piirissä olevien adjektiivien joukkoon. On mahdollista, että kongruenssin synty on varsin myöhäistä ja se on vielä kehittymässä. Sanan šiev osalta on mahdollista, että se on semantiikkansa vuoksi alkanut kongruoida samaan tapaan kuin pyeri.

Adjektiivi pyeri kongruoi pääsanansa kanssa eri tavalla kuin muut kieliopissa esitellyt kongruenssin omaavat adjektiivit (Olthuis 2000: 172). Muilla adjektiiveilla on kongruenssi vain monikossa, mutta pyeri kongruoi myös yksikössä samaan tapaan kuin pohjoissaamessakin (ks. taulukko 6). Näyttää siis siltä, kuten eteläsaamessakin, että sanan pyeri kongruenssi on vanhaa, mutta muiden adjektiivien uutta.

Myös koltassa esiintyy kaksi erilähtöistä sanaa merkityksessä 'hyvä'. Niiden funktiosta ja mahdollisesta suomen kaltaisesta sekaparadigmasta on ristiriitaista tietoa. Koltansaamen opas (Korhonen et al. 1974: 57) antaa ymmärtää, että kielessä on kaksi perusmuotoista sanaa merkityksessä 'hyvä': pue'rr ja šiõgg (= saaIn šiev, saaP šiega), jotka esiintyvät sekä attribuuttina että predikatiivina. Uudemman kieliopin (Moshnikoff \& Koponen 2009: 47) mukaan adjektiivi pue'rr esiintyy vain predikatiivina. Attribuuttina käytetään adjektiivia šiõgg (Moshnikoff \& Koponen 2009: 67). Tämä voi johtua siitä, että uudempi kielioppi on tarkoitettu koulukieliopiksi ja on siksi siis myös normatiivisempi kuin aiempi Koltansaamen opas.

Inarin šiev (InLpW 214: šieu) ja koltan šiõgg ovat sekä etymologisesti että kongruenssin muutoksen takia kiinnostavia. Ne eivät ole suomen hyvä-sanan vastineita, ja niiden lainasuhdekin on epäselvempi kuin eteläsaamen adjektiivilla hijven. Näiden etymologia ulottuu lännessä pohjoissaameen (šiega 'kiltti, hyvä; reilu') ja idässä turjansaameen (š̄gng 'hyvä'), kattaen kaikki itäsaamelaiset kielet (Álgu). Suomen hyvä-sanan vastine lienee pohjoissaamen savvit 'parantua, parantaa' (SSA 1: 201). ${ }^{5}$ Olisi houkuttelevaa esittää inarinsaamen šiev ym. (< ksaa *šieke $)$ itämerensuomalaisiksi lainoiksi. Äännerakenne ei kuitenkaan anna tällaiselle esitykselle tukea. Pohjoissaamen šiega, inarin šiev, koltan šiõgg ja kildininsaamen šĭg vastaavat toisiaan, ja ne voidaan palauttaa kantasaameen muotoon *šieke. Itämerensuomen *y-äännettä ei ole saamessa substituoitu ie:llä, joten lainaetymologia jää huteralle pohjalle.

Kantasaamen *šieke 'hyvä' muistuttaa sekä semanttisesti että muodollisesti (lainautumismielessä, ei äännelaillinen vastine) suomen sanaa sievä, mutta näitä ei ole liitetty toisiinsa. Suomen adjektiivia sievä on pidetty sanojen siivo ja siveä jonkinlaisena kontaminaationa (SSA 3: 174), mutta sanan rajoittuminen vain suomeen voisi viitata myös lainaperäisyyteen (saame $\rightarrow$ suomi, oma arvio).

5. Ellei sitten varhainen laina itämerensuomesta, ks. Koivulehto 2009: 86. 
Saamelaiskielissä tapahtuneesta hajaannuksesta huolimatta on nähtävissä, että ksaa *pōrē 'hyvä' on todennäköisesti taipunut attribuuttiasemassa demonstratiivipronominien tavoin. Erot demonstratiivien ja numeraalien välillä inarinsaamessa koskevat lähinnä akkusatiivin ja genetiivin merkintää. Muutenkaan ei ole kovin selvää, miten paljon pronominit ja numeraalit ovat kongruenssin suhteen eronneet toisistaan. Muiden adjektiivien inkongruenssi ja erilliset attribuuttimuodot ovat nekin palautettavissa kantasaameen saakka, joten jo kantasaamessa on *pōrē kongruoinut pääsanansa kanssa.

Rießler (2011: 189) esittää, että nykyisissä saamelaiskielissä on tendenssi siirtyä adjektiiviattribuutin merkinnässä tunnusmerkittömään muotoon, kuten esimerkiksi pohjoissaamessa tätä nykyä yleisimmällä johtimella -laš (sápmelaš 'saamelainen', girjalaš 'kirjallinen') muodostetuissa adjektiiveissa, joilla ei ole erillistä attribuuttitunnusta. Inarinsaame näyttäisi kuitenkin olevan eri kannalla, koska siellä adjektiiviattribuutin kongruenssi näyttää laajenevan koskemaan kokonaisia adjektiivityyppejä aiempien yksittäisten adjektiivien (lähinnä pyeri) sijaan. Joissakin saamelaiskielissä, kuten koltassa ja eteläsaamessa, adjektiivien komparatiivimuodot kongruoivat pääsanansa kanssa. Se saattaa myös viitata kongruenssin laajenemiseen, ellei sitten kyse ole jäänteestä, esiintyyhän vertailuasteiden kongruenssia sekä lännessä että idässä. Toisaalta, komparatiivin kongruenssi on eteläsaamessa ja koltassa erilaista. Eteläsaamessa se on lukukongruenssia, kun taas koltansaamessa komparatiiveilla on samanlainen "heikon taivutuksen" sijakongruenssi kuin pronomineillakin (Moshnikoff \& Koponen 2009: 51, ks. myös ylempänä, 3.2.1). Inarinsaamessa kongruenssin piirissä ovat superlatiivimuodot, mutta eivät komparatiivimuodot.

\subsection{Mordva}

\subsection{Adjektiivit}

Mordvassa adjektiivi on attribuuttiasemassa yleensä taipumaton. Predikatiiviasemassa adjektiivi kongruoi subjektin kanssa sekä numeruksen että persoonan suhteen: adjektiivilla on ns. predikatiivitaivutus, nominikonjugaatio. 3. persoonassa kongruenssi ilmenee numeruskongruenssina, 1. ja 2. persoonassa persoonakongruenssina. 1. ja 2. persoonassa adjektiivilla on verbin konjugaation persoonapäätteet. (Bartens 1999: 108; Turunen 2010: 167.)

\subsubsection{Demonstratiivipronominit ja numeraalit}

Demonstratiivit kongruoivat pääsanansa kanssa numeruksen suhteen sekä ersässä että mokšassa, (Bartens 1999: 114-115). Ersämordvan oppikirjan (Mosin \& Bajuškin 1983: 117) mukaan ersässä demonstratiivipronominit eivät kongruoi attribuuttina lainkaan sen enempää kuin adjektiivitkaan. Kyse voi olla joko murteellisesta ilmiöstä tai kielessä tapahtuvasta muutoksesta, jossa pronominien kongruenssi katoaa. Alla esimerkki (Bartens 1999: 114): 
Ersä:
(4) ńet' val-tne-ń
nämä sana-PL.DET-GEN/ACC
'näiden sanojen'

Mokša:

(5) $\quad$ ńä ši-t'ńว-ń

nämä päivä-PL.DET-GEN/ACC

'näiden päivien'

Sen sijaan numeraalit eivät pääsanansa edellä taivu. (Bartens 1999: 119.)

\subsubsection{Paro, para ja kongruenssi}

Mordvalaiskielissä E paro, M para 'hyvä' voi kongruoida pääsanansa kanssa luvussa. Se siis käyttäytyy samoin kuin demonstratiivit, ei kuten numeraalit. Ersän murteissa on joitakin muitakin adjektiiveja, jotka kongruoivat luvussa pääsanansa kanssa (Bartens 1999: 108). Itkosen (1966: 320) mukaan lukukongruenssia esiintyy erityisesti monikon nominatiivissa. Alla muutama esimerkki:

Ersä:

(6) par-t t'ejt'er'-t'

hyvä-PL tyttö-PL

'hyvät tytöt'

(7) $a \check{s} O-t$

końov- $t$

(Bartens 1999: 108)

'valkeita papereita'

(8) śijed'e-t' śorma- $t$

(Bartens 1999: 108)

tiheä-PL kirjoitus-PL

'tiheitä kirjoituksia (kirjoitat)'

(9) bera- $t^{\prime}$ loma- $t^{\prime}$

(Itkonen 1966: 320)

paha-PL ihminen-PL

'pahat ihmiset'

Mokša:

(10) par-t st $t^{\prime} i k^{\prime}-t$

(Bartens 1999: 108)

hyvä-PL.NOM tyttö-PL.NOM

'hyvät tytöt' 
Bartensin (1999: 108) esimerkit ovat vanhoja adjektiiveja; ašo 'valkoinen' ja śijed' 'tiheä'. Molemmille adjektiiveille on esitetty suomesta mahdollinen vastine: $a$ šo = sm. ha(a)hkea (SSA 1: 124), śijed' = sm. sikeä (SSA 3: 179). Kumpikin esitetään jokseenkin epävarmoina vastineina. Riippumatta suomen vastineen oikeellisuudesta, nämä sanat ovat joka tapauksessa vanhoja, myös mordvan ulkopuolella esiintyviä sanoja (SSA 3: 179), mikä osaltaan herättää uteliaisuuden sitä kohtaan, mistä murteissa esiintyvä kongruenssi on peräisin. Edellä esitetyt, pääsanansa kanssa mordvassa kongruoivat adjektiivit viittaavat arvoon ('hyvä'), väriin ('valkoinen') ja laajuuteen ('tiheä'). Nämä semanttiset ryhmät ovat niitä, joihin eri kielten adjektiivit viittaavat ensimmäisenä, siis myös kielissä, joissa adjektiivit ovat suljettu luokka (ks. Dixonin jako kohdassa 2).

Satunnaista kaasuskongruenssiakin Bartens (1999: 108) ersästä esittelee, mutta ainakin tarjotut esimerkit ovat varsin runollisia, missä puolestaan voi olla kyse tyylilajista tai kongruenssin käytöstä painotuksen ja tähdentämisen tehokeinona:

(11) $\begin{array}{lllll}a s ̌ o-n & u t k a-n & \text { l'ed'e-me, maźi-ń } & \text { utka-ń } & \text { mašto-mo } \\ \text { valkea-GEN } & \text { sorsa-GEN } & \text { ampua-INF } & \text { kaunis-GEN } & \text { sorsa-GEN tappaa-INF }\end{array}$
'(meni) valkeaa sorsaa ampumaan, kaunista sorsaa tappamaan'6

Bartensin (ibid.) perusteella on oletettavaa, että tällainen esiintymä muiden adjektiivien osalta on murteellista, mutta sanan paro osalta koko kieltä (sekä mokšaa) kattava.

\subsection{Mari}

Marissa sekä adjektiivit että demonstratiivit ovat attribuuttiasemassa taipumattomia (Alhoniemi 1985: 43). Marissa *para-sanan vastine on poro 'hyvä, terve'. Se on attribuuttina esiintyessään taipumaton, kuten muutkin adjektiivit (esimerkit itämarista).

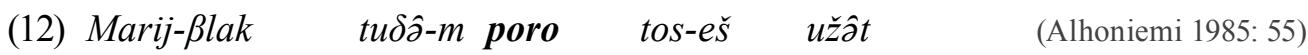
marilainen-PL.Nom hän-ACC hyvä.NOM ystävä-LAT pitää.PRs.3PL

'Marit pitävät häntä hyvänä ystävänä.'

(13) Tide

$$
\text { kenežy-m tol’o }
$$

(Alhoniemi 1985: 51) DEM.PRON.NOM kesä-ACC tulla.PRET.3sG

'Hän tuli tänä kesänä.'

6. Tästä Bartens (1999: 108) esittää myös esimerkin siŕeste at́asto....siŕreste babasto 'vanhasta ukosta ... vanhasta akasta', jossa sana sir' 'vanha' on lainattu samalta suunnalta kuin para, nimittäin varhaiskantairanista (Koivulehto 1999: 221). 
Marissakin on joitakin adjektiiveja, joilla on kaksi muotoa: lyhyempi muoto, jota käytetään attribuuttiasemassa, ja pidempi muoto, jota käytetään muissa asemissa, esimerkiksi (Alhoniemi 1985: 43):
(14) a.
Ta-štz
$\boldsymbol{o s}$
lâm
ulâ.
DEM.PRON-INESS valkea.LYHYT
lumi.Nom
olla.PRS.EXIST.3SG
'Tuolla on valkeaa lunta.'
b. Lâm ošô
lumi.Nom valkea.Nom
'Lumi on valkeaa.'

Tästä pienestä ryhmästä suuren osan muodostavat erilaiset väriä osoittavat adjektiivit, kuten edellisen esimerkin ošâ \# oš 'valkea, vaalea' ja joškarge \# joškar 'punainen'. Osa näistä sanoista on vanhoja. Ainakin edellisessä esimerkissä esiintyvä ošâ 'valkea; vaalea; puhdas' on yhdistetty mordvan sanaan E ašo M akša 'valkoinen' sekä suomen sanaan (h)ah(k)ea 'vaalea' (SSA 1: 124). Sinänsä kiinnostavaa on, että myös ersän murteissa $a \check{s} o$ on yksi niistä sanoista, joilla tavataan attribuuttiasemassa kongruenssia pääsanansa kanssa. Adjektiivilla poro ei ole erillistä lyhyttä muotoa, vaikka sellaista voisi vanhalta adjektiivilta odottaa.

Adjektiivien lisäksi myös demonstratiiveilla ja numeraaleilla 1-9 on lyhyt muoto, jota käytetään vain attribuuttina. Demonstratiivipronominit voivat kongruoida pääsanansa kanssa luvussa, mutta eivät aina; myös yksiköllisillä pronomineilla voidaan viitata monikkoon.

\subsection{Permiläiset kielet}

\subsection{Komi}

Permiläiskielissä pääasiallisesti eivät adjektiivit, demonstratiivipronominit eivätkä numeraalit kongruoi pääsanansa kanssa attribuuttiasemassa. Komin Udoran murteessa adjektiiviattribuutti voi joskus taipua pääsanansa sijan mukaisesti. Ilmiö lienee harvinainen, mutta tästä esimerkkinä on sana bur 'hyvä'. Bartensin mielestä kaasuskongruenssin alueellisuus on osoitus siitä, että se on ilmeisen myöhäistä. (Bartens 2000: 130, 142, 163, 342.)

Komi, Udoran murre:

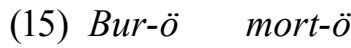
vo-i-s (Bartens 2000: 130) hyvä-ILL ihminen-ILL tulla-PRET-3sg 'Hän tuli hyväksi ihmiseksi' 
Udoran (ja Vymin) murteessa tavataan myös demonstratiiveilla samanlaista kaasuskongruenssia kuin sanalla bur (esimerkki 15, Bartens 2000: 163). Bartensin mukaan tämä on murteellinen ilmiö. Udoran murre on saanut runsaasti vaikutteita itämerensuomesta tiiviiden yhteyksien myötä. Udoran murteessa kuitenkin vain demonstratiivipronominit ja adjektiivi bur kongruoivat attribuuttiasemassa. Koska itämerensuomalaisissa kielissä demonstratiivien ja adjektiivien kongruenssi on attribuuttiasemassa identtistä, on kyseenalaistettava Bartensin oletus siitä, että kongruenssi olisi itämerensuomalaista perua. Olisi odotettavaa, että kyse olisi ennemmin murteessa säilyneestä jäänteestä kuin lainavaikutuksesta. Mikäli kyse on jäänteestä, joka on kadonnut muista komin murteista, voisi ajatella, että itämerensuomen kontaktivaikutus olisi tässä tapauksessa ollut vanhaa säilyttävä.

\subsubsection{Udmurtti}

Udmurtissa adjektiivien ja demonstratiivien suhde on hieman toisenlainen kuin muissa uralilaisissa kielissä. Demonstratiivit eivät kongruoi pääsanansa kanssa sen enempää luvussa kuin sijassa, mutta adjektiivit sen sijaan voivat kongruoida pääsanansa kanssa luvussa. Tällainen kongruenssi ei ole kirjakielen mukaan pakollista, mutta puhekielessä sen verran yleistä, että Hännikäisen ja Kel'makovin kieliopissa (1999: 63) tämä mainitaan.

Tällaisen "vapaaehtoisen" lukukongruenssin lisäksi udmurtissa on determinatiivinen taivutus. Determinatiivinen suffiksi (tai adjektiivin substantiivistaja, Bartens 2000: 131-132) $-\dot{e} z$ on mahdollista lisätä mihin tahansa attributiiviseen sanaan (pronominit, adjektiivit, numeraalit, partisiipit, substantiivit) ja tällöin attribuutti kongruoi pääsanansa kanssa sekä sijassa että luvussa (Hännikäinen \& Kel'makov 1999: 59-60; Rießler 2011: 192). Johdin -ėz on Bartensin (200: 341-342) mukaan possessiivisuffiksi, joka on kongruenssipääte. Tätä käytetään, kun tarkoitetta halutaan erityisesti tähdentää (Rießler 2011: 192):

(13) a. vyl'-ez kńiga

(Bartens 2000: 132)

uUsi-ATTR kirja.NOM.sG

'se uusi kirjoista'

b. $\quad v y l$ 'ez-ly kńiga-ly

(Bartens 2000: 132)

uUsi-ATTR-DAT kirja-SG.DAT

'sille uudelle kirjalle'

c. ćeber-jos-yz l'enta-os

(Bartens 2000: 132)

kaunis-PL-ATTR nauha-PL

'ne kauniit nauhoista' 
Komissakin possessiivisuffiksia käytetään adjektiivin substantiivistajana, mutta se ei kongruoi pääsanansa kanssa (Bartens 2000: 131). Samoin mordvassa adjektiivi substantiivistetaan determinatiivisen taivutuksen keinoin (Bartens 1999: 111). Erona udmurtin järjestelmään on kuitenkin se, että mordvassa se ei esiinny attribuuttiasemassa, vaan itsekseen.

Udmurtin kongruenssi on (esim. suomeen verrattuna) sikäli erikoinen, että attribuuttia merkitsevä -ez ei aina ole samassa paikassa suhteessa taivutuspääteeseen. Possessiivisessa taivutuksessa $-e z$ on ylensä ennen sijapäätettä, mutta illatiivissa, inessiivissä, elatiivissa, egressiivissä, prolatiivissa ja instrumentaalissa se on sijapäätteen jälkeen. Sama taivutus esiintyy myös determinatiivisessa taivutuksessa sen vuoksi, että yksikön 3. persoonan possessiivisuffiksi -ez on siirtynyt ilmaisemaan determinatiivisuutta. Rießler (2011: 144) pitää tätä attribuutin merkintänä, ei determinatiivisena taivutuksena.

Rießler (ibid.) näkee udmurtissa esiintyvän kongruenssin kehityksen paralleelina itämerensuomen ja erityisesti saamen attribuutin merkinnän kehitykselle. Myös inarinsaamessa ja jossain määrin ersässäkin kongruenssia käytetään, kun tarkoitetta halutaan erityisesti tähdentää. Tämä selkeästi on tie kohti systemaattisempaa kongruenssimerkintää.

Udmurtissa adjektiivi bur 'hyvä; oikea' on leksikaalistunut siinä määrin, ettei se esiinny muissa kuin vakiintuneissa ilmauksissa (esim. bur palan 'oikealla puolella', క̌ećbur 'hyvää päivää'), joten sen kongruenssia pääsanan kanssa on vaikeampi seurata. Yleisesti 'hyvää' merkitsevä sana on $u m o j$, joka ei kongruoi pääsanansa kanssa (esim. umoj korkan 'hyvässä talossa', umoj korkaosinn 'hyvissä taloissa').

\subsection{Yhteenveto}

Tässä artikkelissa olen tarkastellut suomalais-permiläisen adjektiivin *para attributiivista kongruenssia kielissä, joissa se esiintyy. Olen verrannut sitä siihen, miten adjektiivit kyseisissä kielissä yleensä käyttäytyvät attribuutteina. Adjektiivien lisäksi olen tarkastellut attribuuttiasemassa toimivien muiden sanaluokkien, erityisesti demonstratiivien, kongruenssia pääsanansa kanssa. Tulokset esitetään kokoavasti taulukon 9 muodossa. 


\begin{tabular}{|l|l|l|l|l|}
\hline kieli & adj. kongr. & dem. kongr. & numer. kongr. & *para kongr. \\
\hline itämerensuomi & sija ja luku & sija ja luku & sija ja luku & $\begin{array}{l}\text { vain komp. } \\
\text { ja sup. }\end{array}$ \\
\hline eteläsaame & $\begin{array}{l}\text { ei (komp. } \\
\text { lukukongr.) }\end{array}$ & puolikongr. & puolikongr. & vain komp. \\
\hline luulajansaame & ei & puolikongr & puolikongr & ei (murt. on) \\
\hline pohjoissaame & ei & puolikongr. & puolikongr. & puolikongr. \\
\hline inarinsaame & yleensä ei & puolikongr. & puolikongr. & puolikongr. \\
\hline koltansaame & $\begin{array}{l}\text { ei (komp. } \\
\text { puolikongr.) }\end{array}$ & puolikongr. & puolikongr. & vain komp. \\
\hline moksa & ei & luku & ei & luku \\
\hline ersä & ei & luku & ei & luku \\
\hline mari & ei & ei & ei & ei \\
\hline komi & ei & ei & ei & ei \\
\hline Udora & ei & sija & ei & sija \\
\hline udmurtti & $\begin{array}{l}\text { luku (ei } \\
\text { pakollinen) }\end{array}$ & ei & ei & ei \\
\hline
\end{tabular}

Taulukko 9. Adjektiivien, demonstratiivien, numeraalien ja *para-sanan kongruenssi.

Taulukosta 9 näkyy, että niissä kielissä, joissa demonstratiivipronominit eroavat adjektiiveista, myös *para eroaa adjektiiveista. Saamelaiskielissä tilanne on ollut alkuaan samankaltainen. Saamesta on kongruenssi paikoin hävinnyt tai häviämässä joko sekaparadigman (eteläsaame) tai jonkinlaisen analogian (luulajansaame, arjeploginsaame) myötä. Komin Udoran murre näyttää * para-sanan kongruenssin ja demonstratiivipronominien kongruenssin osalta samalta kuin muut taulukossa esitetyt kielet. Siksi on vaikea uskoa, että kyse olisi kovin tuoreesta ilmiöstä. On toki mahdollista, että pronominien kongruenssi olisi suomalais-mordvalainen innovaatio, mutta Ravila (1960: 31) tyrmää sen vedoten Irén N.-Sebestyénin samojedista ottamiin esimerkkeihin attribuuttikongruenssista. Myös marissa demonstratiiveilla, numeraaleilla ja muutamilla adjektiiveilla on attribuuttiasemassa erillinen lyhyt muoto (ks. kohta 3.4). Kyse siis voi olla myös vanhasta jäänteestä, vaikkakin noin suppea levikki asettaa oletuksen kyseenalaiseksi. Toisaalta itämerensuomalainen vaikutus on voinut säilyttää Udorassa kongruenssin, vaikka se on muista komin murteista kadonnut.

Tämä tutkimus osoittaa, että saamessa, mordvassa ja komin Udoran murteessa * para eroaa adjektiiveista samalla tavalla kuin demonstratiivit. Tämän vuoksi on oletettavaa, että * para on kongruoinut demonstratiivien tapaan jo alun alkaenkin. Erikoisena pidetty adjektiivi * para on siis samalla tavoin erikoinen eri puolilla kielikuntaa. Se on semanttisesti adjektiivi; merkitys 'hyvä; oikea' on säilynyt varsin stabiilina. Sana * para on semanttisesti adjektiivi, mutta morfosyntaktisilta ominaisuuksiltaan se muistuttaa pronominia. Yksi tulkintavaihtoehto on, että sekä pronominit (attribuuttina käytetyt, tyyppiä tässä talossa) että adjektiivit ovat aiemmin 
kongruoineet pääsanansa kanssa, mikä sittemmin olisi kadonnut. Tämä vaihtoehto ei kuitenkaan vaikuta kovin todennäköiseltä, sillä tässä tapauksessa pitäisi olla säilynyt muitakin vanhoja adjektiiveja, joilla olisi demonstratiivien (tai muiden pronominien) mukainen kongruenssi attribuuttiasemassa (esim. PFU *wudi, Sammallahti 1988: 551). Näin ei kuitenkaan ole ja tässäkin esitelty adjektiivi * para on laina eikä omaperäinen. Vaikka olen mordvan osalta esitellyt sanoja, jotka voivat kongruoida pääsanansa kanssa, ei saamelaiskielten puolella ole kantasaameen palautettavia adjektiiveja, joilla olisi samanlainen kongruenssi kuin adjektiivin *para vastineilla.

Toinen kiinnostava havainto koskee adjektiiviattribuutin kongruenssin laajenemista osassa saamelaiskieliä. Inarin- ja eteläsaamessa näyttäisi attribuutin sijakongruenssi olevan jopa laajenemassa. Inarinsaamessa kongruenssi koskee tällä hetkellä lähinnä monikon taivutusta, joten aika näyttää, kuinka käy. Tosin Bartens (1972: 159) esittää myös yksiköstä kongruenssiesimerkkejä. Hänen mukaansa (Itkoseen viitaten) kongruenssia käytetään, kun tarkoitetta halutaan tähdentää, samaan tapaan kuin udmurtin ja komin determinatiivisessa taivutuksessa. Todennäköisesti myös ersässä esiintyvässä kongruenssissa on kyse tähdentämisestä.

Saamelaiskielet osoittavat tendenssiä siirtyä suomen kaltaiseen suppletiiviseen paradigmaan 'hyvää' tarkoittavien sanojen osalta. Eteläsaamen systeemi lienee suora laina suomesta, kun taas inarin ja koltansaamen järjestelmät painottuvat predikatiiviattribuuttimuodon vaihteluun.

Eteläsaamen ja koltan komparatiivin kongruenssi voi olla joko uusi ilmiö tai sitten vanha jäänne. Inarinsaamessa kongruoi vertailuasteista ainakin superlatiivi. Vertailumuotojen ja tähdennyksen kongruenssi voikin olla avain siihen, miksi *para kongruoi attribuuttiasemassa. Syy voi löytyä lainasanan semantiikasta. Indoeurooppalaisessa kantakielessä se on ollut merkitykseltään superlatiivinen ja todennäköisesti suomen superlatiivi paras on tällaisen merkityksen säilyttänyt. Siksi *para ei ehkä ole ollut perusadjektiivi, vaan jotain muuta; tähdentävä, painottava, kuten pronominit. Semantiikassa, 'hyvän' superlatiiviudessa voi olla myös avain siihen, miksi positiivisen konnotaation omaava sana leksikaalistuu ja muuttuu niin, että syntyy suppletiivisia paradigmoja. 


\section{Lyhenteet}

k.-arj. arjalainen kantakieli

mdE ersämordva

mdM mokšamordva

mint. muinaisintia

saaP pohjoissaame

sm. suomi

vkiran. varhaiskantairani

PFU suomalais-ugrilainen kantakieli

vksm. varhaiskantasuomi

\section{Glossaukset}

$\begin{array}{llll}1 & \text { ensimmäinen persoona } & \text { ILL } & \text { illatiivi } \\ 3 & \text { kolmas persoona } & \text { INESS } & \text { inessiivi } \\ \text { ACC } & \text { akkusatiivi } & \text { INF } & \text { infinitiivi } \\ \text { ABESS } & \text { abessiivi } & \text { LAT } & \text { latiivi } \\ \text { CMPR } & \text { komparatiivi } & \text { LOC } & \text { lokatiivi } \\ \text { COM } & \text { komitatiivi } & \text { M } & \text { maskuliini } \\ \text { DEM.PRON } & \text { demonstratiivipronomini } & \text { PART } & \text { partitiivi } \\ \text { DET } & \text { determinatiivi } & \text { PL } & \text { monikko } \\ \text { EL } & \text { elatiivi } & \text { PREP } & \text { prepositio } \\ \text { ESS } & \text { essiivi } & \text { PRET } & \text { preteriti } \\ \text { EXIST } & \text { eksistentiaali } & \text { PRS } & \text { preesens } \\ \text { GEN } & \text { genetiivi } & \text { SG } & \text { yksikkö }\end{array}$

\section{Lähteet}

Alhoniemi, Alho 1985: Marin kielioppi. Helsinki: Suomalais-Ugrilainen Seura.

Álgu $=A ́ l g u$-tietokanta. Helsinki, Kotimaisten kielten tutkimuskeskus 2006. Päivitetään jatkuvasti. $<$ http://kaino.kotus.fi/algu> 14.7.2013.

Bartens, Raija 1972: Inarinlapin, merilapin ja luulajanlapin kaasussyntaksi. Mémoires de la Société Finno-Ougrienne 148. Helsinki: Suomalais-Ugrilainen Seura.

Bartens, Raija 1999: Mordvalaiskielten rakenne ja kehitys. Mémoires de la Société FinnoOugrienne 232. Helsinki: Suomalais-Ugrilainen Seura.

Bartens, Raija 2000: Permiläisten kielten rakenne ja kehitys. Mémoires de la Société FinnoOugrienne 238. Helsinki: Suomalais-Ugrilainen Seura.

Bergsland, Knut 1994: Sørsamisk grammatikk. Karasjok: Davvi Girji.

Bobaljik, Jonathan David 2012: Universals in Comparative Morphology: Suppletion, Superlatives and the Structure of Words. Current Studies in Linguistics. Cambridge, Massachussets \& London: The MIT Press.

Corbett, Greville G. 2006: Agreement. Cambridge Textbooks in Linguistics. Cambridge: Cambridge Unversity Press.

Csúcs, Sándor 2005: Die Rekonstruktion der permischen Grundsprache. Budapest: Akadémiai Kiadó.

Hakulinen, Lauri 1979: Suomen kielen rakenne ja kehitys. 4. korjattu painos. Helsinki: Suomalaisen Kirjallisuuden Seura.

Haspelmath, Martin 2010: Comparative concepts and descriptive categories in cross-linguistic studies. - Language 86: 663-687. 
Honti, László 1997: Fremdes oder Eigenständiges? Zum historischen Hintergrund der Attributivkongruenz in uralischen Sprachen. - Sirkka-Liisa Hahmo \& Tette Hofstra \& László Honti \& Paul van Linde \& Osmo Nikkilä (toim.), Finnisch-ugrische Sprachen in Kontakt. Vorträge des Symposiums aus Anlaß des 30-jährigen Bestehens der Finnougristik an der Rijksuniversiteit Groningen 21.-23. November 1996. Maastricht: Shaker Publishing. 135-144.

Hännikäinen, Sara \& Kel'makov, Valentin 1999: Udmurtin kielioppia ja harjoituksia. Apuneuvoja suomalais-ugrilaisten kielten opintoja varten XIV. Helsinki: Suomalais-Ugrilainen Seura.

InLpW = Itkonen, Erkki 1986-1989: Inarilappisches Wörterbuch I-IV. Unter mitarbeit von Raija Bartens und Lea Laitinen. Lexica Societatis Fenno-Ugricae XX. Helsinki: Suomalais-Ugrilainen Seura.

Itkonen, Erkki 1966: Kieli ja sen tutkimus. Helsinki: WSOY.

Itkonen, Esa 2001: Maailman kielten erilaisuus ja samuus. 2., uudistettu ja laajennettu painos. Yleisen kielitieteen julkaisuja 4. Turku: Turun yliopisto.

Jalava, Lotta 2013: "Adjectives" in Tundra Nenets: Properties of Property Words. - Journal de la Société Finno-Ougrienne 94. 37-67.

Koivulehto, Jorma 1999: Varhaiset indoeurooppalaiskontaktit: aika ja paikka lainasanojen valossa. - Paul Fogelberg (toim.): Pohjan poluilla. Suomalaisten juuret nykytutkimuksen mukaan. Bidrag till kännedom av Finlands natur och folk 153. Helsinki: Societas Scientiarum Fennica. 207-236

Koivulehto, Jorma 2009: Etymologisesti hämäriä -(is)TA-johdosverbejä, lainoja ja omaperäisiä. - Journal de la Société Finno-Ougrienne 92. Helsinki: Suomalais-Ugrilainen Seura. $79-102$.

Korhonen et al. $=$ Mikko Korhonen \& Jouni Mosnikoff \& Pekka Sammallahti 1974: Koltansaamen opas. Castrenianumin toimitteita 4. Helsinki: Suomalais-Ugrilainen Seura.

Korhonen, Mikko 1981: Johdatus lapin kielen historiaan. Helsinki: Suomalaisen Kirjallisuuden Seura.

Lehtiranta, Juhani 1992: Arjeploginsaamen äänne- ja taivutusopin pääpiirteet. Mémoires de la Société Finno-Ougrienne 212. Helsinki: Suomalais-Ugrilainen Seura.

Lehtiranta, Juhani 2001: Yhteissaamelainen sanasto. Mémoires de la Société Finno-Ougrienne 200. 2. painos. Helsinki: Suomalais-Ugrilainen Seura.

LuLpW = Grundström, Harald 1946-1954: Lulelapsk ordbok. Skrifter utgivna genom Landsmåls- och folkminnesarkivet i Uppsala. 1. Uppsala: A.-B. Lundequitiska bokhandeln.

Mel'čuk, Igor 1993: Agreement, government, congruence. - Lingvisticae Investigationes 17: 307-372.

Mosin, M. V. \& Bajuškin, N. S. 1983: Ersämordvan oppikirja. Apuneuvoja suomalais-ugrilaisten kielten opintoja varten VIII. Helsinki: Suomalais-Ugrilainen Seura.

Moshnikoff, Satu \& Moshnikoff, Jouni \& Koponen, Eino 2009: Koltansaamen koulukielioppi. Inari: Saamelaiskäräjät.

Nickel, Klaus Peter 1994: Samisk grammatikk. Karasjok: Davvi Girji.

Olthuis, Marja-Liisa 2000: Kielâoppâ. Inarinsaamen kielioppi. Inari: Sämitigge.

Pajunen, Anneli 1998: Pääsanaluokkien eriytymättömyydestä uralilaisissa kielissä. - Anneli Pajunen (toim.): Analogiasta, typologiasta ja kieliopillistumisesta. Suomi 185. Helsinki: Suomalaisen Kirjallisuuden Seura. 59-109. 
Ravila, Paavo 1953: Sanaluokat, erityisesti uralilaisia kieliä silmällä pitäen. - Virittäjä 57: 41-50.

Ravila, Paavo 1960: Adjektiiviattribuutin kongruenssin synty suomen kielessä. - Sananjalka 2: 28-34.

Rießler, Michail 2011: Typology and evolution of adjective attribution marking in the languages of northern Eurasia. Revised version of June 7th, 2012. < http://omnibus.unifreiburg.de/ mr5496/downl/RIESSLER2011.pdf>

Sammallahti, Pekka 1998: The Saami Languages - An Introduction. Karasjok: Davvi Girji.

SSA 1-3 = Itkonen, Erkki \& Ulla-Maija Kulonen (toim.) 1992-2000: Suomen sanojen alkuperä. Etymologinen sanakirja. Suomalaisen Kirjallisuuden Seuran Toimituksia 556 \& Kotimaisten kielten tutkimuskeskuksen julkaisuja 62. Helsinki: Kotimaisten kielten tutkimuskeskus \& Suomalaisen Kirjallisuuden Seura.

Turunen, Rigina 2010: Nonverbal Predication in Erzya. Studies on morphosyntactic variation and part of speech distictions. Tohtorinväitöskirja. Helsingin yliopiston suomalaisugrilaisen kielentutkimuksen laitos.

UEW = Rédei, Karoly 1988-1991: Uralisches etymologisches Wörterbuch I-III. Wiesbaden: Otto Harrassowitz. 